\title{
Strategi dalam kegiatan Crowdfunding
}

\section{Cahyo Adityo Irawan}

\section{S130118033@student.ubaya.ac.id}

Crowdfunding adalah sejenis crowdsourcing dengan memungkinkan masyarakat untuk terlibat dalam proyek sosial untuk berkontribusi pada sumber daya dalam mengatasi masalah sosial, yang memiliki tujuan yang sama dengan crowdsourcing dalam kegiatan kemanusiaan. Crowdfunding disebut sebagai jenis crowdorganising, termasuk “ spot transaction, hubungan jangka pendek, harga berbasis permintaan, permintaan heterogen, dan reputasi yang dibangun melalui mekanisme feedback. Praktik usaha sosial terkait dengan inisiatif sosial Crowdfunding mengatasi masalah sosial dengan mengadopsi pendekatan bisnis. Berbagai jenis crowdfunding berupaya menyeimbangkan peran berbagai pemangku kepentingan. Praktik crowdfunding adalah cara untuk mengembangkan aktivitas usaha melalui proses penggalangan dana, di mana wirausahawan sosial menyesuaikan kampanye mereka dengan lebih baik daripada di platform standar. Prosesnya melibatkan sekelompok orang yang mengumpulkan uang melalui Internet untuk mendukung proyek tertentu. Kontribusi finansial terdiri dari berbagai jenis, antara lain lending, equity, reward dan donation. Sistem pendidikan dasar dan perawatan kesehatan yang lemah adalah masalah paling umum di negara berkembang ini yang menjadi perhatian utama pada praktik crowdfunding usaha sosial. Oleh karena itu, konsep wirausaha sosial bermunculan dengan berbagai model, seperti organisasi nirlaba dan koperasi serta usaha kemasyarakatan.

Dalam pendidikan, situs crowdfunding menawarkan kesempatan untuk membiayai kegiatan sosial dengan terlibat dalam bisnis pariwisata tidak hanya untuk mengunjungi tempat tersebut tetapi juga untuk berbagi pengetahuan dengan anak-anak sekolah di daerah terpencil. Pada tahap awal, organisasi mengundang teman dan keluarga yang sebagian besar berasal dari kota metropolitan, yaitu Amsterdam dan Jakarta. Usai mengunjungi masyarakat di pulau-pulau terpencil, para pengunjung tertarik menjadi relawan untuk memberikan ceramah kepada anakanak sekolah melalui media online. (Pratono, et al., 2020)

Penelitian crowdfunding dapat dibagi menjadi tiga sub-tema: donasi publik, crowdfunding, dan penelitian masaah. Urun dana untuk kepentingan publik adalah bentuk lain dari donasi. Studi ini mengkaji mekanisme penggalangan dana dan mobilisasi sumber daya kesejahteraan masyarakat, sistem mobilisasi sumber daya, dan perilaku donasi perusahaan. Penelitian sebelumnya juga meneliti penggunaan dana amal dan distribusi sumber daya amal. Namun, studi ini sering kali menggunakan data tangan pertama dari donor, tetapi jarang menggunakan data objektif (Liu, Cheng, \& Wang, 2020)

Crowdfunding merupakan fenomena yang berkembang pesat, seperti dalam semua skenario di mana arus uang antar individu, membutuhkan regulasi dan pemantauan yang tepat. Bukti dari penelitian ini dengan jelas menunjukkan bahwa platform crowdfunding harus diperlukan untuk memastikan uji tuntas secara ketat, yang dapat dicapai jika, misalnya, pembuat kebijakan akan menetapkan standar. Evolusi teknologi baru telah memungkinkan organisasi dan 
individu untuk membangun hubungan bisnis di seluruh dunia melalui platform virtual. Oleh karena itu, platform ini telah menjadi alat yang diperlukan dan berguna untuk memotivasi wirausahawan baru untuk menjalankan ide-idenya, memberikan solusi untuk masalah sarana keuangan. Pilihan untuk menggunakan satu jenis platform atau lainnya akan bergantung pada sejumlah faktor yang dianggap perlu oleh promotor gagasan untuk proyek tersebut, dan disoroti hal berikut: jenis crowdfunding, waktu kampanye, tujuan pembiayaan, platform untuk sistem pembayaran, daya tarik web, dan akses dana pelengkap. (Borrero-Domininguez, CordonLagares, \& Hernandez-Garrido, 2020)

Model crowdfunding ekuitas menunjukkan bagaimana individu mencari kepentingan pengendali dari suatu organisasi. Dalam jenis model crowdfunding ini, penyandang dana mengalokasikan sumber daya keuangan untuk menerima imbalan finansial dari investasi mereka. Model ini sangat berbeda dari platform crowdfunding berbasis reward, yang memberikan reward terbatas, seperti produk itu sendiri atau pengakuan untuk mendanai usaha. Jumlah ambang minimum untuk urun dana ekuitas cukup rendah untuk mendorong investor konvensional mengambil bagian dalam inovasi sosial. Aktivitas crowdfunding dengan produk dengan kompleksitas rendah mendapatkan manfaat dari persepsi dan kepercayaan produk yang disukai. Sebaliknya, keberhasilan crowdfunding dengan produk dengan kompleksitas tinggi membangkitkan persepsi dan kepercayaan produk yang lebih disukai. Kegiatan tersebut mungkin berguna untuk menghadapi ketidakpastian pasar dengan melengkapi antara angel dan crowd investor yang membawa manfaat penting bagi investasi ventura. Kualitas usaha yang lebih tinggi dengan sumber daya manusia yang substansial berdampak positif pada kesuksesan pendanaan pada platform crowdfunding ekuitas. (Pratono, et al., 2020)

\section{Bibliography}

Borrero-Domininguez, C., Cordon-Lagares, E., \& Hernandez-Garrido, R. (2020). Analysis of Success factors in crowdfunding projects based on rewards: A way to obtain financing for socially comitted projects. Heliyon, 6, 1-9. doi:10.1016/j.heliyon.2020.e03744

Liu, S., Cheng, T., \& Wang, H. (2020). Effects of Attention and Reliability on the Performance of Online Medical Crowdfunding Projects: The Moderating Role of Target Amount. Journal of Management Science and Engineering, 32, 1-22. doi:10.1016/j.jsme.2020.08.004

Pratono, A. H., Prima, D. A., Sinaga, N. F., Permatasari, A., Ariani, M., \& Han, L. (2020). Crowdfunding in Digital Humaities: Some Evidence from Indonesian Social Enterprises. Aslib Journal of Information, 72(2), 297-303. doi:10.1108/AJIM-05-2019-0123 